\title{
The Determinants of Corporate Liquidity in Real Estate Industry: Evidence from Vietnam
}

\author{
Truong Hong Trinh ${ }^{1} \&$ Phan Thi Thuy Mai ${ }^{1}$ \\ ${ }^{1}$ University of Economics, The University of Danang, Vietnam \\ Correspondence: Truong Hong Trinh, Faculty of Finance, University of Economics, Danang City, Vietnam. Tel: \\ 84-511-352-5459. E-mail: trinh.th@ due.edu.vn
}

Received: March 21, 2016

Accepted: April 5, 2016

Online Published: June 25, 2016

doi:10.5539/ijef.v8n7p21

URL: http://dx.doi.org/10.5539/ijef.v8n7p21

\begin{abstract}
This paper investigates the impact of firm size, profitability, cash flows, investment opportunities, leverage and capital expenditure on cash holding level and cash conversion cycle for 54 listed real estate companies in Vietnam stock exchange during 2010-2014. The empirical result highlights two most important variables that affect the cash holdings-profitability and capital expenditure that have strong influence on the corporate liquidity of these real estate companies. The study also indicates that policies on cash holdings and working capital investment have been affected under financially constrained conditions. The study result provides speculative motive of cash holdings as well as the emphasis of financial constraints on the adjustment of working capital investment in the real estate industry.
\end{abstract}

Keywords: corporate liquidity, cash holding, cash conversion cycle, real estate industry, Vietnam

\section{Introduction}

Real estate market is closely linked to the capital market that effects to the health of the economy. The real estate market can not reach a strong and sustainable development without the stable capital market. The proportion of Vietnam real estate, which varies in different countries, accounts for $40 \%$ of the whole national assets, and nearly $30 \%$ of total economic activities. In the real estate industry, profitability and liquidity are important indicators in financial decisions. While the financial decisions mainly focus on traditional solvency ratios and the capital structure of companies, the corporate liquidity is related to decisions on working capital management. How to establish a target working capital to improve operating performance and maximize firm value is still a big question that is much attractive to many researchers and practitioners in the literature.

Cash holding levels and the cash conversion cycle are closely related to each other that will enhance the firm value. Anjum and Malik (2013) used cash holdings to investigate the determinants of corporate liquidity. Cash conversion cycle is referred to as liquidity measures (Maness \& Zietlow, 2004) and used in previous studies (Valipour, Moradi, \& Farsi, 2012), (Attari \& Raza, 2012), (Owolabi \& Obida, 2012). Thus, this study uses cash holding level and cash conversion cycle as representatives of corporate liquidity. Although the corporate liquidity have been studies in cross nation scope in different circumstances, there is no study on cash holdings and cash conversion cycle as the corporate liquidity in Vietnam. For the purpose of the study, this paper investigates determinants of corporate liquidity and its impact in real estate companies listed on Vietnam stock exchange during 2010-2014.

\section{Literature Review}

\subsection{Cash Holding Level}

Cash is usually defined as cash-in-hand and short-term marketable securities or cash equivalents (Opler, Pinkowitz, Stulz, \& Williamson, 1999; Ferreira \& Vilela, 2004; Bates, Kahle, \& Stulz, 2009). The cash holding level is measured by the cash over total assets. These are common determinants used in previous study and their relationship with cash holding level.

\subsubsection{Firm Size}

According to Opler et al. (1999), firms that have the greatest access to the capital markets, such as large frms and those with high credit ratings, tend to hold lower ratios of cash to total non-cash assets. Ferreira and Vilela (2004) 
concluded that the size and the level of cash holding is negatively correlated because it is more expensive for small firms to raise funds in the borrowing markets; larger firms are more likely have diversified business portfolio, so they are less vulnerable to financial distress. Meanwhile, Pinkowitz and Williamson (2001) have contrasting results in their studies.

H1: There is a negative relationship between firm size and cash holdings.

\subsubsection{Profitability}

Dobetz and Grüninger (2006) proposed cash and profits are substitute, thus they have a negative relationship to each other. Nguyen (2006) investigated a study on a sample of 9,168 firm-year observations from Tokyo Stock Exchange for the period of 1992 to 2003. Regression analysis recognized a positive relationship between profitability and cash holdings.

H2: There is a positive relationship between profitability and cash holdings.

\subsubsection{Cash Flow}

According to Kim, Mauer, and Sherman (1998), cash flow can be seen as cash substitutes. Thus it is expected that there is a negative relation between cash flow and cash holdings. Opler et al. (1999) argued that firms with riskier cash flows hold relatively high ratios of cash to total non-cash assets. Pinkowitz and Williamson (2001) has found evidence of a positive influence of cash flow on cash holdings.

\section{H3: There is a positive relationship between cash flows and cash holdings.}

\subsubsection{Investment Opportunity}

According to Ferreira and Vilela (2004), when a firm has greater investment opportunity, the firm will have greater bankruptcy cost, the firm will hold more cash in order to avoid financial distress. Kim et al. (1998) found evidence of a positive relationship between investment opportunity and cash holdings. J. Kim, H. Kim, and Woods (2011) also found evidence to support this direct relationship. They argued that firms with higher investment opportunities tend to hold more cash because cash holdings reduce the likelihood of financial distress and act as a safety reserve to cope with unexpected losses due to cash shortages or external fund-raising constraints.

\section{H4: There is a positive relationship between investment opportunity and cash holdings.}

\subsubsection{Leverage}

Hardin, Highfield, Hill, and Kelly (2009) argued that leverage impose a negative effect on cash holdings as leverage can be used as a mechanism to minimize agency costs in free cash flow problem. In contrast to this argument, A. Ozkan and N. Ozkan (2004) in their sample of all UK firms over the period 1984-1999 found that higher cash holdings are associated lower level of leverage in firms' capital structure. As explained by Ferreira and Vilela (2004), leverage increases the probability of bankruptcy, thus firms with higher leverage are expected to hold more cash to reduce the probability of experiencing financial distress.

\section{H5: There is a negative relationship between leverage and cash holdings.}

\subsubsection{Capital Expenditure}

According to Bates et al. (2009), the inverse relation between cash holding demand and borrowing capacity leads to an inverse relation between capital expenditure and cash holdings. However, Opler et al. (1999) found that cash holdings increased significantly as capital expenditures increased.

H6: There is a negative relationship between capital expenditure and cash holdings.

Table 1. Previous studies on cash holding level

\begin{tabular}{|c|c|c|c|}
\hline Variables & Authors approving positive relationship (+) & Authors approving negative relationship (-) & Hypotheses development \\
\hline Firm size & Pinkowitz and Williamson (2001) & $\begin{array}{l}\text { Faulkender (2002), Bover and Watson } \\
\text { (2005), Ferreira and Vilela (2004) }\end{array}$ & H1-Negative \\
\hline Profitability & Nguyen (2006) & Dobetz and Grüninger (2006) & H2-Positive \\
\hline Cash flow & $\begin{array}{l}\text { Opler et al. (1999), Pinkowitz and Williamson } \\
\text { (2001) }\end{array}$ & $\begin{array}{l}\text { Kim et al (1998), } \\
\text { Ferreira and Vilela (2004) }\end{array}$ & H3-Positive \\
\hline Investment opportunit & Ferreira and Vilela (2004), J. Kim et al. (2011) & & H4-Positive \\
\hline Leverage & Ferreira and Vilela (2004) & Hardin et al. (2009), & H5-Negative \\
\hline Capital expenditure & Opler et al. (1999) & Bates et al. (2009) & H6-Negative \\
\hline
\end{tabular}




\subsection{Cash Conversion Cycle}

Cash conversion cycle (CCC) is defined as the length of time from the payment for the purchase of raw materials to manufacture a product until the collection of account receivables associated with the sale of the product (Besley \& Brigham, 2005). The CCC is calculated by taking into account three components: days inventory outstanding (DIO), days sales outstanding (DSO), days payables outstanding (DPO).

\subsubsection{Firm Size}

Firm size also has its influence on the management of working capital. Large companies have more bargaining power with suppliers and customers compared to small companies. (Berger, Klapper, \& Udell, 2001) and (Jordan, Lowe, \& Taylor, 1998) argued that the cost of investment in working capital would be lower for larger firms compared to smaller one since larger corporations have lower information asymmetry and thus lower cost of external financing. Moreover, larger firms have better access to capital markets and have larger capacity to extend more trade credits that enable them to have more investment in working capital as compared to smaller firms (Petersen \& Rajan, 1997).

H1: There is a positive relationship between firm size and cash conversion cycle.

\subsubsection{Profitability}

Working capital and profitability have interrelationships. On the one hand, more profitability makes firms stronger to negotiate with both suppliers and customers, and firms can use these competitive advantages to improve their liquidity (Petersen \& Rajan, 1997). On the other hand, working capital has important effects on profitability. More investment in working capital means more sources engaged and make more opportunity cost for firms (Deloof, 2003).

\section{H2: There is a negative relationship between profitability and cash conversion cycle}

\subsubsection{Cash Flow}

Pecking order theory (Myers \& Majluf, 1984) demonstrates that firms prioritize their sources of financing from internal financing to equity since internal sources are cheaper than other finance alternatives. As a result, working capital management would be sensitive to the cash flow and firms with more cash flow would afford to have more investment in working capital requirement. Fazzari and Petersen (1993) argued that firms with larger cash flow have more working capital because these firms have more internal sources to financing working capital and enable to have higher current asset levels.

\section{H3: There is a positive relationship between cash flow and cash conversion cycle.}

\subsubsection{Investment Opportunity}

Up to now, there is no study providing evidence of the existence of a correlation between investment opportunity and cash conversion cycle. When firms are able to make more profit in the future, they have a tendency to increase their investment in working capital as speculative motive. Therefore, a positive relationship between investment opportunities and cash conversion cycle is hypothesized.

\section{H4: There is a positive relationship between investment opportunity and cash conversion cycle.}

\subsubsection{Leverage}

Leverage shows the ratio of total debt to total assets. When this ratio is high, it indicates that internal investment is low and firms need to finance their operations. Baños - Caballero, García - Teruel, and Martínez - Solano (2010) indicated that there is a negative relationship between debt and cash conversion cycle. In other words, a firm with low needs of working capital needs to finance from debt.

H5: There is a negative relationship between leverage and cash conversion cycle.

\subsubsection{Capital Expenditure}

The level of investment in fixed assets would affect the efficiency of working capital management. Fazzari and Petersen (1993) believed that the level of working capital might compete with the fixed investment for the available source of finance. Therefore, firms may try to reduce the amount of working capital investments to handle their financial constraints.

\section{H6: There is a negative relationship between capital expenditure and cash conversion cycle}

All of the measurements of firm size, leverage, investment opportunity, cash flows, profitability and capital expenditure in the relation with cash conversion cycle are the same as those in the relation with cash holding level. 
Table 2. Previous studies on cash conversion cycle

\begin{tabular}{|c|c|c|c|}
\hline Variables & Authors approving positive relationship $(+)$ & $\begin{array}{l}\text { Authors approving negative relationship } \\
\qquad(-)\end{array}$ & $\begin{array}{r}\text { Hypotheses } \\
\text { developmen }\end{array}$ \\
\hline Firm size & $\begin{array}{l}\text { Berger et al. (2001), Jordan et al. (1998), } \\
\text { Petersen \& Rajan (1997) }\end{array}$ & Petersen \& Rajan (1997) & H1-Positive \\
\hline Profitability & & $\begin{array}{l}\text { Petersen \& Rajan (1997) } \\
\text { Deloof (2003) }\end{array}$ & H2-Negative \\
\hline Cash flow & $\begin{array}{l}\text { Fazzari \& Petersen (1993) } \\
\text { Myers \& Majluf (1984) }\end{array}$ & & H3-Positive \\
\hline $\begin{array}{l}\text { Investment } \\
\text { opportunity }\end{array}$ & 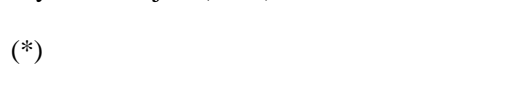 & & H4-Positive \\
\hline Leverage & & Baños - Caballero et al. (2010) & H5-Negative \\
\hline Capital expenditure & & Fazzari \& Petersen (1993) & H6-Negative \\
\hline
\end{tabular}

Note. $(*)$ There is no study providing evidence of the existence of a correlation between investment opportunities and cash conversion cycle.

\section{Data and Methodology}

\subsection{Data}

The data used in this study is derived from the annual report of real estate companies listed on Ho Chi Minh Stock Exchange and Hanoi Stock Exchange. The total number of real estate companies is 54. The annual reports are obtained from $31^{\text {st }}$, December 2010 to $31^{\text {st }}$, December 2014 . There are 270 observations for the whole sample.

Table 3. The summary of variables in the study

\begin{tabular}{lcccccccc}
\hline Variables & CR & CCC & TA & ROA & CF & PB & LEV \\
\hline Mean & 0.0591 & 4258.8250 & 3839.4780 & 0.0309 & 0.0321 & 0.7124 & 0.5441 & 0.0315 \\
Median & 0.0214 & 960.6599 & 1451.1160 & 0.0218 & 0.0250 & 0.6313 & 0.5494 & 0.0043 \\
Maximum & 0.8149 & 175726.9 & 90485.31 & 0.2701 & 0.2597 & 3.5077 & 0.9154 & 0.4682 \\
Minimum & 0.0004 & 30.7495 & 111.7027 & -0.2123 & -0.1532 & 0.0000 & 0.1137 & 0.0000 \\
Std. Dev. & 0.1027 & 16571.1300 & 9161.8680 & 0.0554 & 0.0499 & 0.5782 & 0.1577 & 0.0641 \\
Skewness & 4.3228 & 8.5092 & 6.2652 & 0.3882 & 0.9190 & 1.9610 & -0.1926 \\
Kurtosis & 27.2418 & 79.3434 & 49.8729 & 7.3260 & 6.6516 & 8.8563 & 2.5384 & 20.2653 \\
Observations & 270 & 270 & 270 & 270 & 270 & 270 & 270 \\
\hline
\end{tabular}

The mean cash ratio of the real estate companies is $5.9 \%$ with a standard deviation of $10.27 \%$, which indicates a right-skewed distribution of cash ratio. Similarly, the cash conversion cycle has the mean value of 4259 days with standard deviation of 9162 days, which denotes a clear right-skewed distribution. Thus, cash ratio (CR) and cash conversion cycle (CCC) are taken under the nature logarithm form. The average total asset of this sample is 3839 billion VND with a standard deviation of 9162 billion VND, indicating wide variance across firms. Average return on asset (ROA) is $3.09 \%$, which belongs to the bottom group in terms of ability to generate profit as reported by Vietstock. Average cash flow from operations $(\mathrm{CF})$ is only 0.032 , implying that this industry has a low capacity to generate cash inflows. The average of market-to-book-value ratio (PB), at 0.7124 , reveals that our current capital markets is undervaluing with the sampled real estate companies. The mean value of leverage (LEV) is $54.41 \%$, which reinforces the fact that real estate companies rely more heavily on debt than on equity for financing. The mean value of capital expenditure (CE) only accounts for $3.15 \%$ of total assets, which is a low proportion in comparison to the cash ratio.

\subsection{Methodology}

This study follows previous studies to define the formulas associated with each variable. According to J. Kim et al. (2011), the cash holding level is measured by the cash over total assets. (Charitou, Elfani, \& Lois, 2010) and (Valipour et al., 2012) used the cash conversion cycle in their studies as a comprehensive indicator of liquidity. To reduce the asset variance among companies, this study measures firm size as the natural logarithm of total assets, as suggested by J. Kim et al. (2011). (Dobetz \& Grüninger, 2006) and Valipour et al. (2012) used return on assets to measure profitability (ROA). As suggested by (Opler et al., 1999), (A. Ozkan \& N. Ozkan, 2004), 
(Ferreira \& Vilela, 2004), cash flow is measured by the ratio of earnings after interests, dividends, taxes but before depreciation and amortization to total assets (CF). This study will follow J. Kim et al. (2011) to measure investment opportunity as the market-to-book-value ratio. According to many empirical findings, leverage is measured as the ratio of total liabilities to total assets (LEV). Based upon previous studies, capital expenditure (CE) is measured as the ratio of capital expenditure to total assets. Table 4 summarizes how to measure all kinds of variables used in this study

Table 4. The measurement of variables in the study

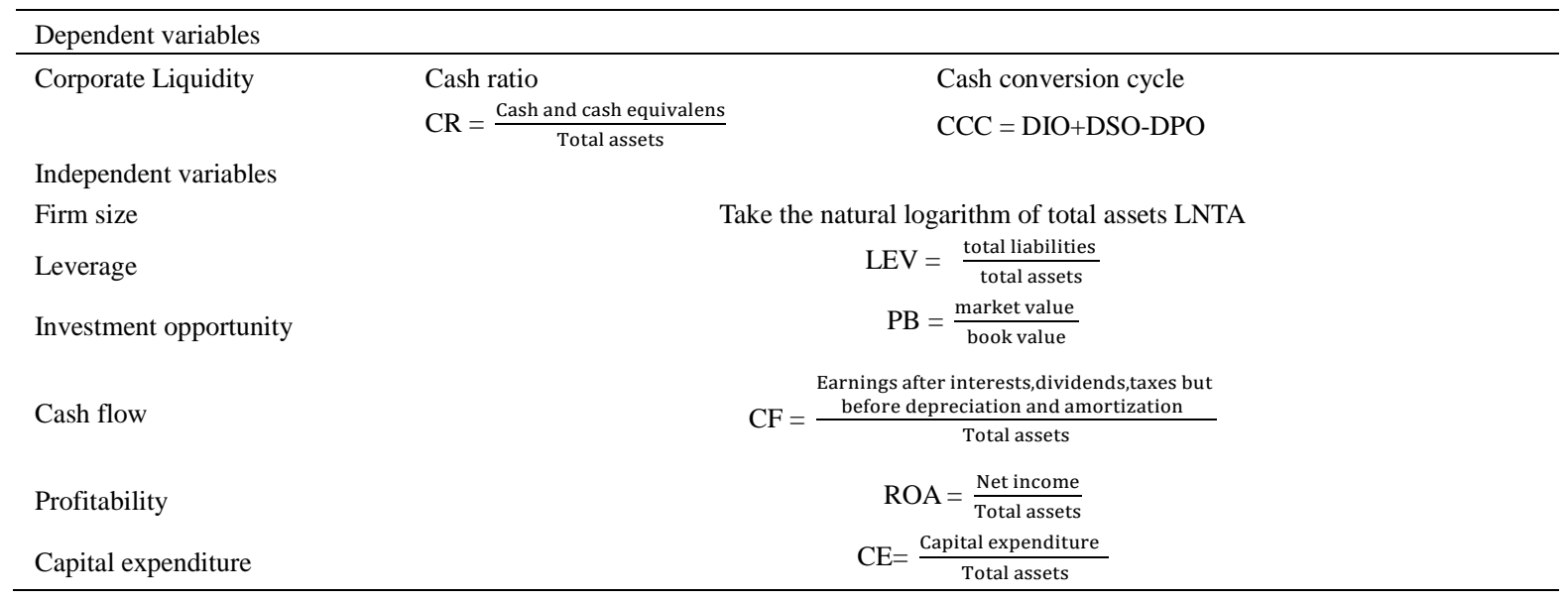

This study combines the descriptive statistics derived from the data and the facts in the real estate market to reinforce of clear perspective of this market. Then, the Pearson correlation matrix is used to check the correlation between variables. The weighted least-squares (WLS) or ordinary least-squares (OLS) is used to examine the impact of firm size, leverage, investment opportunity, cash flows, profitability, capital expenditure in explaining the determinants of corporate liquidity in real estate industry. The reason for using WLS is because this study involves a cross sectional time series data, which may result in the problem of heteroskedasticity and violates the constant residual assumptions of OLS.

Real estate companies are also separated into financially constrained firms and unconstrained firms based on the criteria suggested by Custodio, Ferreira, and Raposo (2004). Financially constrained firms are those with total assets over 5-year period smaller than the first quartile point. Financially unconstrained firms are those with total assets over 5-years period larger than the third quartile point. The rationale behind this is to test the extent of each variable on firms of different financial conditions besides testing the effects of variables on the whole sample. After obtaining regression models, this study uses the VIF test to detect multicollinearity and White-test to detect heteroskedasticity.

All the six models in this study are built in the form of multivariate linear model as follows:

Model 1 (Cash holding level-Whole sample)

$$
L N C R_{i, t}=\beta_{0}+\beta_{1} L N T A_{i, t}+\beta_{2} R O A_{i, t}+\beta_{3} C F_{i, t}+\beta_{4} P B_{i, t}+\beta_{5} L E V_{i, t}+\beta_{6} C E_{i, t}+\varepsilon_{i, t}
$$

Model 2 (Cash holding level - Financially constrained firms)

$$
L N C R_{i, t}=\beta_{0}+\beta_{1} L N T A_{i, t}+\beta_{2} R O A_{i, t}+\beta_{3} C F_{i, t}+\beta_{4} P B_{i, t}+\beta_{5} L E V_{i, t}+\beta_{6} C E_{i, t}+\varepsilon_{i, t}
$$

Model 3 (Cash holding level - Financially unconstrained firms)

$$
L N C R_{i, t}=\beta_{0}+\beta_{1} L N T A_{i, t}+\beta_{2} R O A_{i, t}+\beta_{3} C F_{i, t}+\beta_{4} P B_{i, t}+\beta_{5} L E V_{i, t}+\beta_{6} C E_{i, t}+\varepsilon_{i, t}
$$

Model 4 (Cash conversion cycle - Whole sample)

$$
L N C C C_{i, t}=\beta_{0}+\beta_{1} L N T A_{i, t}+\beta_{2} R O A_{i, t}+\beta_{3} C F_{i, t}+\beta_{4} P B_{i, t}+\beta_{5} L E V_{i, t}+\beta_{6} C E_{i, t}+\varepsilon_{i, t}
$$

Model 5 (Cash conversion cycle - Financially constrained firms)

$$
L N C C C_{i, t}=\beta_{0}+\beta_{1} L N T A_{i, t}+\beta_{2} R O A_{i, t}+\beta_{3} C F_{i, t}+\beta_{4} P B_{i, t}+\beta_{5} L E V_{i, t}+\beta_{6} C E_{i, t}+\varepsilon_{i, t}
$$

Model 6 (Cash conversion cycle - Financially unconstrained firms)

$$
L N C C C_{i, t}=\beta_{0}+\beta_{1} L N T A_{i, t}+\beta_{2} R O A_{i, t}+\beta_{3} C F_{i, t}+\beta_{4} P B_{i, t}+\beta_{5} L E V_{i, t}+\beta_{6} C E_{i, t}+\varepsilon_{i, t}
$$




\section{Results and Discussion}

\subsection{Empirical Results}

Table 5 shows that cash ratio is positively and significantly correlated with firms size, investment opportunity, cash flows, profitability and capital expenditure. Leverage is the only variable that has significantly negative association with cash ratio.

Table 5. Pearson correlation coefficient matrix - cash holding level

\begin{tabular}{|c|c|c|c|c|c|c|c|}
\hline Variables & LNCR & LNTA & LEV & PB & $\mathrm{CF}$ & ROA & $\mathrm{CE}$ \\
\hline LNCR & 1.0000 & & & & & & \\
\hline LNTA & 0.0607 & 1.0000 & & & & & \\
\hline LEV & -0.0590 & 0.1853 & 1.0000 & & & & \\
\hline $\mathrm{PB}$ & 0.2130 & 0.3368 & 0.1487 & 1.0000 & & & \\
\hline $\mathrm{CF}$ & 0.3047 & -0.1168 & 0.0094 & 0.1489 & 1.0000 & & \\
\hline ROA & 0.4763 & -0.0213 & -0.1126 & 0.2275 & 0.7302 & 1.0000 & \\
\hline $\mathrm{CE}$ & 0.1778 & 0.0666 & 0.0008 & 0.2029 & 0.1101 & 0.1732 & 1.0000 \\
\hline
\end{tabular}

Table 6 shows that cash conversion cycle is positively and significantly correlated with firm size and leverage, and is negatively correlated with investment opportunity, cash flow, profitability and capital expenditure.

Table 6. Pearson correlation coefficient matrix - cash conversion cycle

\begin{tabular}{|c|c|c|c|c|c|c|c|}
\hline Variables & LNCCC & LNTA & LEV & PB & $\mathrm{CF}$ & ROA & $\mathrm{CE}$ \\
\hline LNCCC & 1.0000 & & & & & & \\
\hline LNTA & 0.2705 & 1.0000 & & & & & \\
\hline LEV & 0.1377 & 0.1853 & 1.0000 & & & & \\
\hline $\mathrm{PB}$ & -0.1206 & 0.3368 & 0.1487 & 1.0000 & & & \\
\hline $\mathrm{CF}$ & -0.4043 & -0.1168 & 0.0094 & 0.1489 & 1.0000 & & \\
\hline ROA & -0.4008 & -0.0213 & -0.1126 & 0.2275 & 0.7302 & 1.0000 & \\
\hline $\mathrm{CE}$ & -0.2678 & 0.0666 & 0.0008 & 0.2029 & 0.1101 & 0.1732 & 1.0000 \\
\hline
\end{tabular}

Table 7 and Table 8 summarize regression results for identifying the factors that affect cash holding level and cash conversion cycle in the whole sample and two groups of financially constrained and unconstrained firms. The White test and the VIF are also presented at the end of each model for reference.

Table 7. Regression models of cash holding level

\begin{tabular}{lccc}
\hline \multirow{2}{*}{ Variables } & \multicolumn{3}{c}{ Cash Ratio (LNCR) } \\
\cline { 2 - 4 } & Model 1 & Model 2 & Model 3 \\
\cline { 2 - 4 } LNTA & Whole sample & Financially constrained sample & Financially unconstrained sample \\
ROA & 0.0194 & 0.3936 & $0.4380^{* *}$ \\
CF & $12.2334^{* *}$ & $18.0456^{* *}$ & $21.7544^{* *}$ \\
PB & -1.3166 & -10.2881 & -9.2444 \\
LEV & $-0.3781^{* *}$ & -0.2473 & -0.2312 \\
CE & $1.1391^{* *}$ & 1.4683 & 0.0429 \\
Constant & $4.3721^{* *}$ & $5.8052^{* *}$ & 1.3365 \\
Observations & -5.2524 & -15.2390 & -17.1867 \\
Adjusted R-squared & 270 & 70 & 70 \\
White-test (p-value) & 0.3581 & 0.1559 & 0.3864 \\
Mean VIF & 0.00013 & $0.1041^{* *}$ & $0.5493^{* *}$ \\
\hline
\end{tabular}

Note. *: Coefficient is significant at 0.04 level; **: Coefficient is significant at 0.05 level.

The empirical study on cash holding level with the whole sample data indicates that ROA, PB, LEV, CE are 
statistically significant at the 0.05 level as in Table 7 .

The positive coefficient of ROA supports the transaction motive of cash holdings. This motive implies that profitable firms intentionally hold more cash to smooth daily transactions. This finding is consistent with the study of determinants of cash holdings in Tokyo Stock Exchange by Nguyen (2006).

Investment opportunity has a negative impact on the level of cash holdings. Although this result contrasts to previous studies that needs to take a look at the reality of real estate industry in Vietnam. For the last few years, after the notorious "real estate bubble" phenomenon which has a destructive impact on the development of this industry, many leading companies in this field have been frozen in their trading activities. To respond to many investment opportunities, real estate companies choose to invest in inventory instead of cash.

Leverage exerts a positive impact on cash holding level of firms. This result is consistent with studies of Ferreira and Vilela (2004). High leveraged firms might be expected to hold more cash because of their higher bankruptcy risks. As mentioned earlier, the proportion of debt to total assets accounts for more than $50 \%$ across real estate companies. Recently, tighten capital flows from banks have discouraged real estate firm holding more cash to deal with periodical debt repayment, which supports the transaction motive.

Capital expenditure imposes a positive impact on cash holding level. For the recovering real estate industry, the increase of capital expenditure goes with the increase of cash holdings because firms may use up their borrowing capacity secured by capital expenditures in exchange for cash available to deal with unexpected events. This reasoning is consistent with the discussion made before regarding the current circumstance of Vietnam real estate industry. The unpredictability of this industry leads to such prudent financial decisions.

The empirical study on cash conversion cycle with the whole sample data indicates that LNTA, ROA, CF, PB, $\mathrm{CE}$ are statistically significant at the 0.05 level as in Table 8 .

The positive coefficient of LNTA indicates that cash conversion cycle is positively affected by firm size. The negative coefficients of ROA, CF, PB, CE indicates that profitability, cash flow, investment opportunity and capital expenditure impose an indirect impact on cash conversion cycle. Most of these relationships are consistent with previous studies but for the cash flow variable.

The positive coefficient of LNTA is consistent with Berger et al. (2001) and Jordan et al. (1998). The cost of investment in working capital would be lower for larger firms compared to smaller one since larger corporations have lower information asymmetry and thus lower cost of external financing. Moreover, larger firms have better access to capital markets and have larger capacity to extend more trade credits that enable them to have more investment in working capital as compared to smaller firms. All above reasons motivate larger firms to invest more in working capital, thus increasing the cash conversion cycle.

The negative relationship between profitability and cash conversion cycle can be explained by the argument that more profitability makes firms stronger to negotiate with both suppliers and customers, and firms can use these competitive advantages to improve their liquidity (Petersen \& Rajan, 1997). Although the negative coefficients of CF and PB in this model are statistically significant, it is not appropriate for the practical condition of Vietnam real estate companies.

Table 8. Regression models of cash conversion cycle

\begin{tabular}{lccc}
\hline \multirow{2}{*}{ Variables } & \multicolumn{3}{c}{ Cash Conversion Cycle (LNCCC) } \\
\cline { 2 - 4 } & Model 4 & Model 5 & Model 6 \\
\cline { 2 - 4 } LNTA & Whole sample & Financially constrained firms & Financially unconstrained firms \\
ROA & $0.3168^{* *}$ & $1.1401^{* *}$ & -0.0939 \\
CF & $-4.5253^{* *}$ & $-34.5869^{* *}$ & $-19.0611^{* *}$ \\
PB & $-6.0670^{* *}$ & 1.8343 & -2.6625 \\
LEV & $-0.2908^{* *}$ & $2.0722^{* *}$ & 0.2842 \\
CE & 0.7963 & 0.8736 & -0.6933 \\
Constant & $-4.8070^{* *}$ & -22.3171 & $-4.3736^{* *}$ \\
Observations & -1.6603 & -23.3442 & 11.4285 \\
Adjusted R-squared & 270 & 70 & 70 \\
White-test (p-value) & 0.2943 & 0.5918 & 0.3819 \\
Mean VIF & $0.0468^{*}$ & 0.00004 & $0.256^{* *}$ \\
\hline
\end{tabular}

Note. *: Coefficient is significant at 0.04 level; **: Coefficient is significant at 0.05 level. 


\subsection{Discussion}

\subsubsection{Cash Holding Level}

Profitability is the most consistent variable to explain the changes of cash holding level regardless of their types of real estate companies. Whether a company is under financial constraint or not, they tend to hoard more cash when they can generate more profit. This is definitely not a surprise under real circumstances of Vietnam economy where many unanticipated crisis have destroyed a potential real estate industry. That is the reason why this industry deal with its liquidity more prudently, in which the highly profitable companies intentionally hold more cash. There are two reasons for this. Firstly, cash is not cost-free sources so that unprofitable firms hold unless they have a clear motive to make use of this source to enhance value for their companies. Secondly, cash is increasingly essential in firms with high demand of cash to ensure the transaction motive to be responded. In fact, the profitable firms need more cash to smooth the daily goods purchasing and selling activities.

\subsubsection{Cash Conversion Cycle}

Profitability and capital expenditure are the most consistent variables to explain the changes of cash conversion cycle in real estate industry. The highly profitable firms will take advantage of its stable condition to negotiate with contractors and material suppliers. Lengthening the payment term is more feasible than expediting the collection period. This can be explained by the fact that this industry has experienced a freezing stage when the supply too far exceeds the demand. Therefore, once trading transaction occurs, the sellers have to use attractive payment term - meaning longer collection period to encourage final customers' purchasing decisions. For lowly profitable firms, they are forced to invest much more in the operating cycle. They not only stock a large amount of inventory, bear a long collection period but also impossibly lengthen the payment term as highly profitably firms.

The negative relationship of capital expenditure with cash conversion cycle over three sets of data indicates that there exists the competence between capital expenditure and working capital in this industry. This reveals a practical condition not only in real estate industry but also in other industries. The finance sources to firms are limited no matter how good their businesses are. Firms frequently have to face with a lot of constraints to make a decision on what should be given heavy investment, what should be overlooked so that this decision can bring the most value to its shareholders and firm's future prospect.

\section{Conclusion}

This study highlights two most important variables that affect corporate liquidity - profitability and capital expenditure. Both cash holding level and cash conversion cycle have a statistically significant relationship with profitability and capital expenditure. While profitability is positively correlated with cash holding level, it is negatively correlated with cash conversion cycle. This trend comes from the condition of real estate industry, in which profitable firms have a tendency to invest more in cash to grasp opportunity in the future as speculative motive and deal with unexpected events as precautionary motive, but they invest less in working capital because they are capable of negotiating with partners for longer payment terms and shorter collection period.

Capital expenditure has a positive relationship with cash holding level, but a negative relationship with cash conversion cycle. On the one hand, working capital and capital expenditure belongs to contrasting kind of assets, the higher level of one of them requires a lower level of the other due to the existence of financial constraints. On the other hand, cash holdings is supportive of the existence of capital expenditure, more cash available also requires more fixed assets for future need of growth and expansion. A slight difference between two types of firms is the heavier impact of profitability on financially unconstrained firms than on financially constrained firms. This implies that the more profitable firms with stable financial strength, the more cash they intentionally hold to reinforce the certainty of their profit. The study result provides speculative motive of cash holdings as well as the emphasis of financial constraints on the adjustment of working capital investment in the real estate industry.

\section{References}

Aktas, N., Croci, E., \& Petmezas, D. (2015). Is working capital management value-enhancing? Evidence from firm performance and investments. Journal of Corporate Finance, 30, 98-113. http://dx.doi.org/10.1016/j.jcorpfin.2014.12.008

Anjum, S., \& Malik, Q. A. (2013). Determinants of corporate liquidity - An analysis on cash holdings. Journal of Business and Management, 7(2), 94-100.

Attari, M. A., \& Raza, K. (2012). The Optimal Relationship of Cash Conversion Cycle with Firm Size and 
Profitability. International Journal of Academic Research in Business and Social Sciences, 2(4), 189-203.

Baños-Caballero, S., García-Teruel, P. J., \& Martínez-Solano, P. (2010). Working capital management in SMEs. Accounting \& Finance, 50(3), 511-527. http://dx.doi.org/10.1111/j.1467-629X.2009.00331.x

Bates, T. W., Kahle, K. M., \& Stulz, R. M. (2009). Why do US firms hold so much more cash than they used to? The Journal of Finance, 64(5), 1985-2021. http://dx.doi.org/10.1111/j.1540-6261.2009.01492.x

Berger, A. N., Klapper, L. F., \& Udell, G. F. (2001). The ability of banks to lend to informationally opaque small $\begin{array}{lllll}\text { businesses. Journal of Banking \& } & \text { Finance, 25(12), }\end{array}$ http://dx.doi.org/10.1016/S0378-4266(01)00189-3

Besley, S., \& Brigham, E. (2005). Principles of Finance. Ohio: SouthWestern.

Bover, O., \& Watson, N. (2005). Are there economies of scale in the demand for money by firms? Some panel data $\begin{array}{lllll}\text { estimates. Journal of } & \text { Monetary }\end{array}$ http://dx.doi.org/10.1016/j.jmoneco.2004.10.010

Charitou, M. S., Elfani, M., \& Lois, P. (2010). The effect of working capital management on firm's profitability: Empirical evidence from an emerging market. Journal of Business \& Economics Research (JBER), 8(12), 63-68. http://dx.doi.org/10.19030/jber.v8i12.782

Custodio, C., Ferreira, M. A., \& Raposo, C. (2004). Cash holdings and business conditions. Working paper, ISCTE Business Schoool-Lisbon.

Deloof, M. (2003). Does working capital management affect profitability of Belgian firms? Journal of Business Finance \& Accounting, 30(3-4), 573-588. http://dx.doi.org/10.1111/1468-5957.00008

Dobetz, W., \& Grüninger, M. C. (2006). Corporate cash holdings: Evidence from a different institutional setting (No. 2006/06). WWZ Discussion Paper.

Faulkender, M. W. (2002). Cash holdings among small businesses. Available at SSRN 305179. http://dx.doi.org/10.2139/ssrn.305179

Fazzari, S. M., \& Petersen, B. C. (1993). Working capital and fixed investment: New evidence on financing constraints. The RAND Journal of Economics, 328-342. http://dx.doi.org/10.2307/2555961

Ferreira, M. A., \& Vilela, A. S. (2004). Why do firms hold cash? Evidence from EMU countries. European Financial Management, 10(2), 295-319. http://dx.doi.org/10.1111/j.1354-7798.2004.00251.x

Hardin III, W. G., Highfield, M. J., Hill, M. D., \& Kelly, G. W. (2009). The determinants of REIT cash holdings. The Journal of Real Estate Finance and Economics, 39(1), 39-57. http://dx.doi.org/10.1007/s11146-007-9103-1

Jordan, J., Lowe, J., \& Taylor, P. (1998). Strategy and financial policy in UK small firms. Journal of Business Finance \& Accounting, 25(1-2), 1-27. http://dx.doi.org/10.1111/1468-5957.00176

Kim, C. S., Mauer, D. C., \& Sherman, A. E. (1998). The determinants of corporate liquidity: Theory and evidence. Journal of Financial and Quantitative Analysis, 33(3), 335-359. http://dx.doi.org/10.2307/2331099

Kim, J., Kim, H., \& Woods, D. (2011). Determinants of corporate cash-holding levels: An empirical examination of the restaurant industry. International Journal of Hospitality Management, 30(3), 568-574. http://dx.doi.org/10.1016/j.ijhm.2010.10.004

Maness, T. S., \& Zietlow, J. T. (2004). Short-term financial management. South-Western College Pub.

Myers, S. C., \& Majluf, N. S. (1984). Corporate financing and investment decisions when firms have information that investors do not have. Journal of Financial Economics, 13(2), 187-221. http://dx.doi.org/10.1016/0304-405X(84)90023-0

Nguyen, P. (2006). How Sensitive are Japanese Firms to Earnings Risk? Evidence from Cash Holdings. http://dx.doi.org/10.2139/ssrn.889502

Opler, T., Pinkowitz, L., Stulz, R., \& Williamson, R. (1999). The determinants and implications of corporate cash holdings. Journal of Financial Economics, 52(1), 3-46. http://dx.doi.org/10.1016/S0304-405X(99)00003-3

Owolabi, S. A., \& Obida, S. S. (2012). Liquidity management and corporate profitability: Case study of selected manufacturing companies listed on the Nigerian stock exchange. Business Management Dynamics, 2(2), $10-25$.

Ozkan, A., \& Ozkan, N. (2004). Corporate cash holdings: An empirical investigation of UK companies. Journal of 
Banking \& Finance, 28(9), 2103-2134. http://dx.doi.org/10.1016/j.jbankfin.2003.08.003

Petersen, M. A., \& Rajan, R. G. (1997). Trade credit: Theories and evidence. Review of Financial Studies, 10(3), 661-691. http://dx.doi.org/10.1093/rfs/10.3.661

Pinkowitz, L., \& Williamson, R. (2001). Bank power and cash holdings: Evidence from Japan. Review of Financial Studies, 14(4), 1059-1082. http://dx.doi.org/10.1093/rfs/14.4.1059

Valipour, H., Moradi, J., \& Farsi, F. D. (2012). The impact of company characteristics on working capital management. Journal of Applied Finance and Banking, 2(1), 105-125.

\section{Copyrights}

Copyright for this article is retained by the author(s), with first publication rights granted to the journal.

This is an open-access article distributed under the terms and conditions of the Creative Commons Attribution license (http://creativecommons.org/licenses/by/3.0/). 